\title{
Water Relations in Soils as Related to Plant Communities in Ruby Valley, Nevada
}

\author{
R.F. MILLER, F.A. BRANSON, I.S. MCQUEEN, AND C.T. SNYDER
}

\begin{abstract}
Distinct patterns of vegetation on ancient lake sediments in Ruby Valley, Nev., define differences in soij-water-plant relations resulting either from differences in depth to ground water or from differences in water-retention capacities of soils deriving water only from precipitation. In order of increasing depth to ground water, dominant plant species are Juncus balticus, Distichlis stricta, Potentilla fruticosa, Elymus cinereus, Sarcobatus vermiculatus, and Chrysothamnus nauseosus. Dominant species on soils in order of increasing water-retention capacity are Artemesia tridentada nova, Chrysothamnus viscidiflorous pumilus, Ceratoides lanata, Artemesia tridentada tridentada, Atriplex nuttallii gardneri, and $A$ triplex confertifolia. Minimum and ma ximum levels of soil-water stress measured were systematically related to waterretention capacities of soils. A relationship was defined that permits approximation of amounts of water evapotranspired by different plant communities from percent of area under live plant cover. There are separate relationships, relating plant cover to amounts of plant stress or to amount of water evapotranspired, for habitats that receive water from the water table and those that do not. Levels of osmotic stress encountered in surface soils appear to influence plant-community distribution.
\end{abstract}

Plant communities found in habitats ranging from mesic to xeric, and on sediments ranging from clay to gravel in Ruby Valley, Nev., (Fig. 1) provided an opportunity to investigate soil-waterplant relationships under a wide range of conditions. The information obtained is directly applicable to similar high valleys in the Great Basin. Knowledge obtained concerning mechanisms of moisture retention by soils and its subsequent depletion by evapotranspiration has even wider potential for application.

\section{Study Area and Methods Used}

Sediments varying in texture from gravel to clay were deposited in a perennial lake that occupied the valley floor in the glacial and early post-glacial ages. Runoff from the surrounding mountains recharges ground water and still feeds two small lakes on the valley floor. Marsh vegetation occurs at the fringes of both lakes. Vegetation that utilizes ground water occurs in higher areas that are not flooded when the lake levels fluctuate. Several kinds of desert shrubs grow farther from the lakes where ground water occurs at depths below the reach of plant roots. Water for these desert-plant communities is limited to moisture derived directly from precipitation. Lake expansion was greatest when conditions favored the growth of glaciers in the surrounding mountains. Annual precipitation during this period was probably about $500 \mathrm{~mm}(20 \mathrm{in}$.) compared to $300 \mathrm{~mm}$ (12 in.) today (Snyder and Langbein 1962).

Sampling sites were established in three separate portions of the ancient lake bed soccurring in Ruby Valley. Eight plant communities were defined and sampled in the bed of Franklin Lake and its embayment. The bed of Ruby Lake also provided eight different communities to sample. Only five plant communities were available for sampling in the area where the Franklin River flowed into Franklin Lake.

\footnotetext{
The authors are, respectively, hydrologist (soils), botanist, hydrologist (retired), and geologist (retired), U.S. Geological Survey, WRD, Box 25046, Denver Federal Center, Denver, Colorado 80225.
}

The general aspect of the plant community at each study site was phot ographed. Measurements of kinds and amounts of vegetation were made along $15.24-\mathrm{m}(50 \mathrm{ft})$ transects using the first-contact point-quadrat method of Levy and Madden (1933). A pressure chamber of the type described by Waring and Cleary (1967) was used to measure internal-plant stress of the dominant shrub species at each site.

The soils at each site were sampled after snowmelt in the spring and again in the fall to define moisture storage and depletion in soil profiles. A tubular auger $50.8 \mathrm{~mm}(2 \mathrm{in}$.) in diameter was used to extract soil samples in consecutive increments from each soil profile. All the soil obtained from each $0.1 \mathrm{~m}$ (3.9 in.) depth increment was retained for analysis. This permitted determination of bulk density as well as the water content and the related level of soilwater stress. Soil-water stress in each depth increment at the moment of extraction was determined from the water content of filter papers at moisture equilibrium with the soil, as prescribed by McQueen and Miller (1968). Water contents of both the soil and

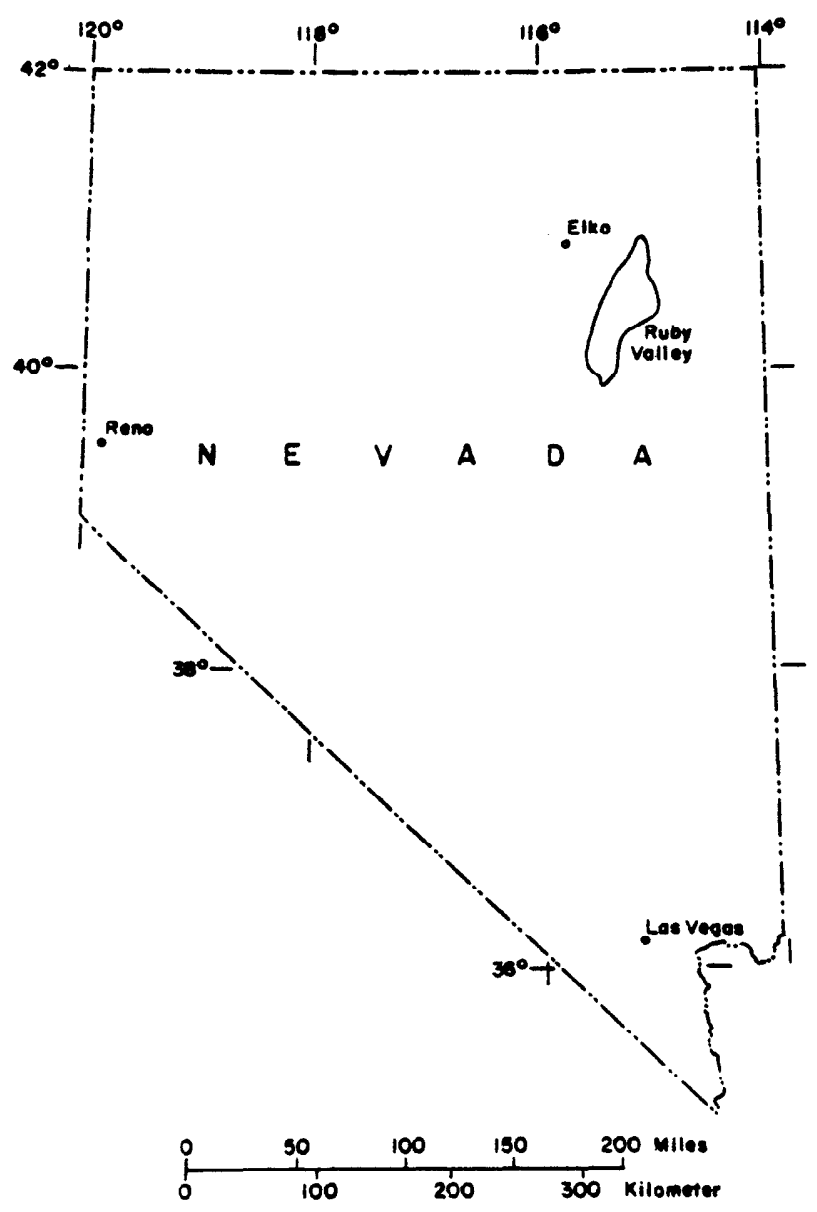

Fig. 1. Index map of Nevada showing the location of Ruby Valley where plant communities and soils were studied. 
filter papers were determined gravimetrically after drying them at $110^{\circ} \mathrm{C}$. Water contents are computed as grams of water per gram of soil or as a percent. Soil-water stress is presented as the logarithm or exponent to the base 10 of the stress in grams per square centimeter $\left(\mathrm{g} / \mathrm{cm}^{2}\right)$. Stress presented in this manner is analogous to $\mathrm{pF}$, as defined by Schofield (1935). A stress of $1 \mathrm{~g} / \mathrm{cm}^{2}$ is equivalent to the pressure exerted on an area of $1 \mathrm{~cm}^{2}$ by a column of water 1 $\mathrm{cm}$ high. A stress of $1020 \mathrm{~g} / \mathrm{cm}^{2}$ is also equivalent to a negative water potential of 1000 milibars or 1 bar. Thus, stresses of 1,10 , 100 , and $1000 \mathrm{~g} / \mathrm{cm}^{2}$ are presented as $10^{0}, 10^{1}, 10^{2}$, and $10^{3} \mathrm{~g} / \mathrm{cm}^{2}$, respectively, and so forth. Use of exponential notation permits the
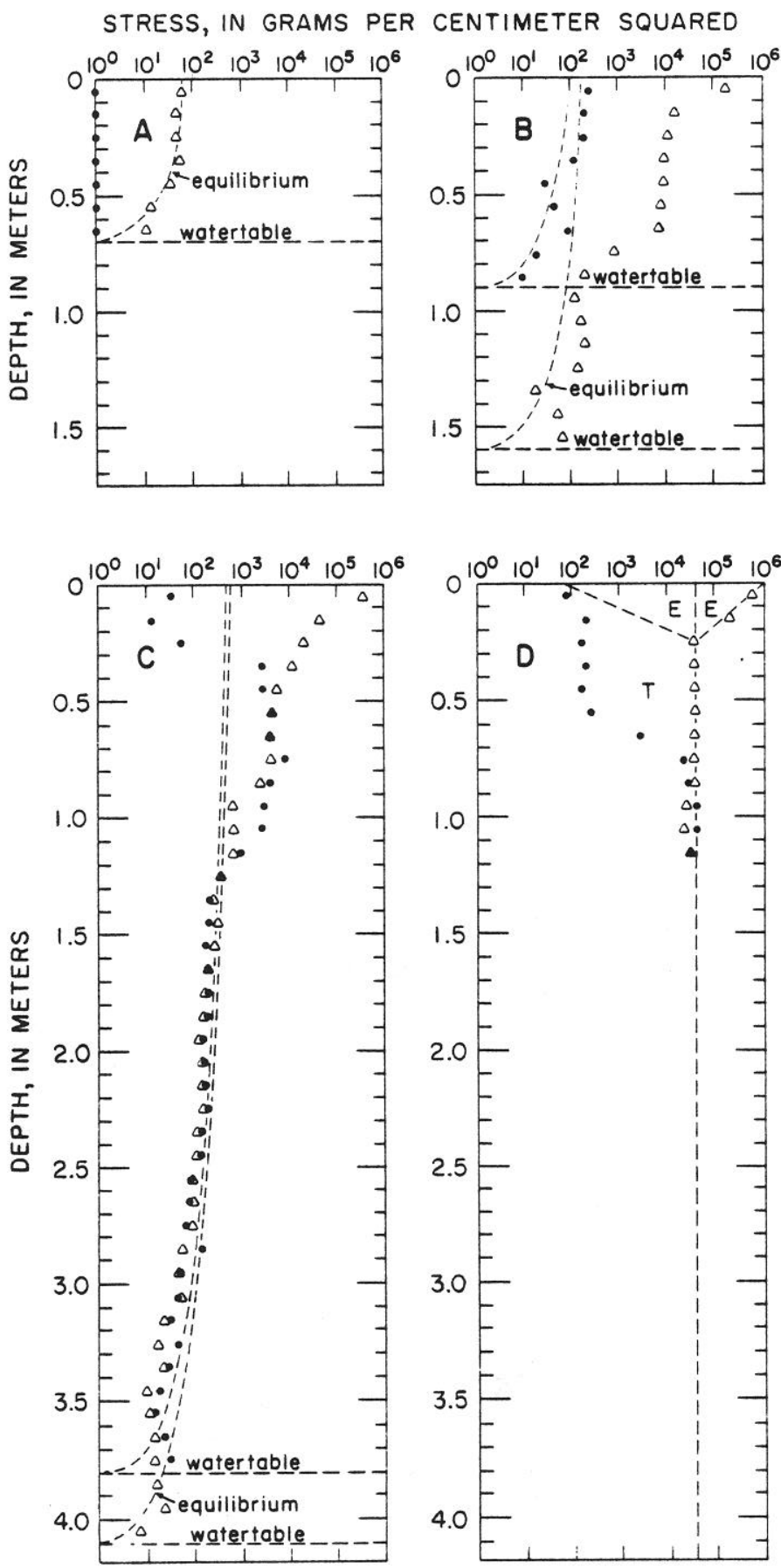

Fig. 2. Patterns of minimum and maximum soil-water stress in soil profiles of four different soil-water environments encountered in Ruby Valley. Levels of stress measured in spring are indicated by circles; fall measurements are indicated by triangles. In the $D$ portion of the figure, $E$ represents evaporation and $T$ refers to transpiration. use of straight-line regression relationships to approximate soilwater contents over a wide range of soil-water stress, as prescribed by McQueen and Miller (1974). Quantities of water, depleted from storage by evapotranspiration, were computed as differences between maximum and minimum levels of storage. Each ovendried sample was subsequently saturated with distilled water and its water content, $\mathrm{pH}$, and electrical conductivity at saturation determined by methods of Richards (1954).

\section{Results and Conclusions}

\section{Moisture Environments}

Four different moisture environments defined in Ruby Valley are illustrated in Figure 2. Minimum levels of soil-water stress were measured at periods approaching maximum wetness in the spring; and maximum levels of soil-water stress were measured at periods approaching minimum levels of water content in the fall. Capillary equilibrium curves, computed as the logarithm or exponent to the base 10 of the height above the water table in centimeters, are
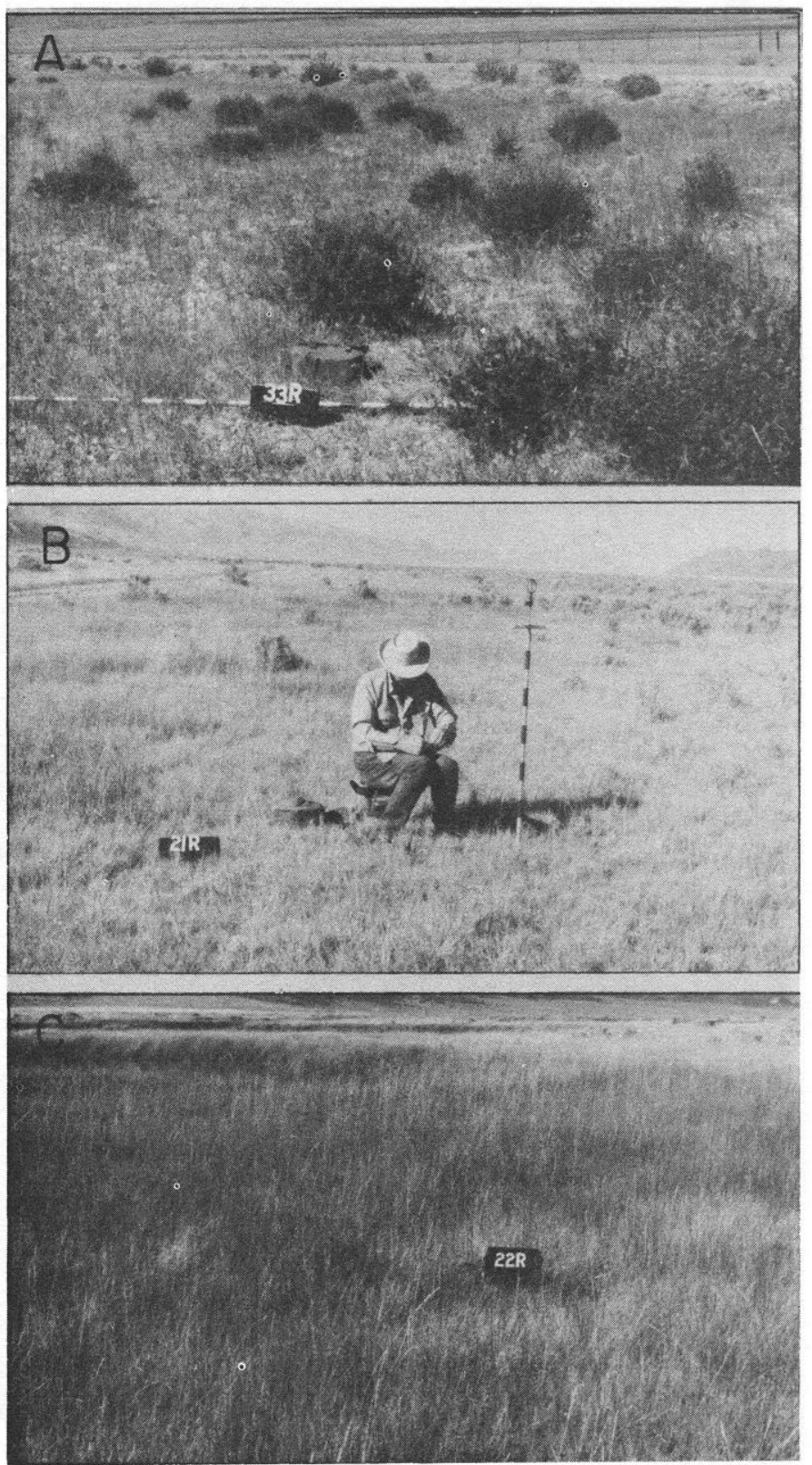

Fig. 3. Plant communities characteristic of bottom sediments where the water table periodically rises to the surface are: (A) shrubby cinquefoil and saltgrass, $(B)$ saltgrass, and (C) baltic rush. 
plotted for sites where depth to the water table was measured (McQueen and Miller 1972). The environment illustrated in Figure $2 \mathrm{~A}$ is representative of sites on bottom sediments where the water table periodically rises to the surface and causes flooding. Plant communities occupying such sites a re illust rated in Figure 3. Dominant species on these sites were: shrubby cinquefoil (Potentilla fruitcosa L.) (nomenclature follows that of Harrington 1954) (Fig. 3A); saltgrass (Distichlis stricta (Torr.) Rydb.) (Fig. 3B); and baltic rush (Juncus balticus Willd.) (Fig. 3C). Soil-water stress for high water-table (flooded) conditions were assumed to be zero for the whole profile. Under low water-table conditions, stress values approached those expected at capillary equilibrium with height above water table.

An environment where the water table does not occur at the surface, but approaches near enough for water to rise to the surface by capillarity is illustrated in Figure 2B. Plant communities associated with this environment are shown in Figure 4. Rubber rabbitbrush (Chrysothamnus nauseosus (Pall.) Britt. nauseosus)
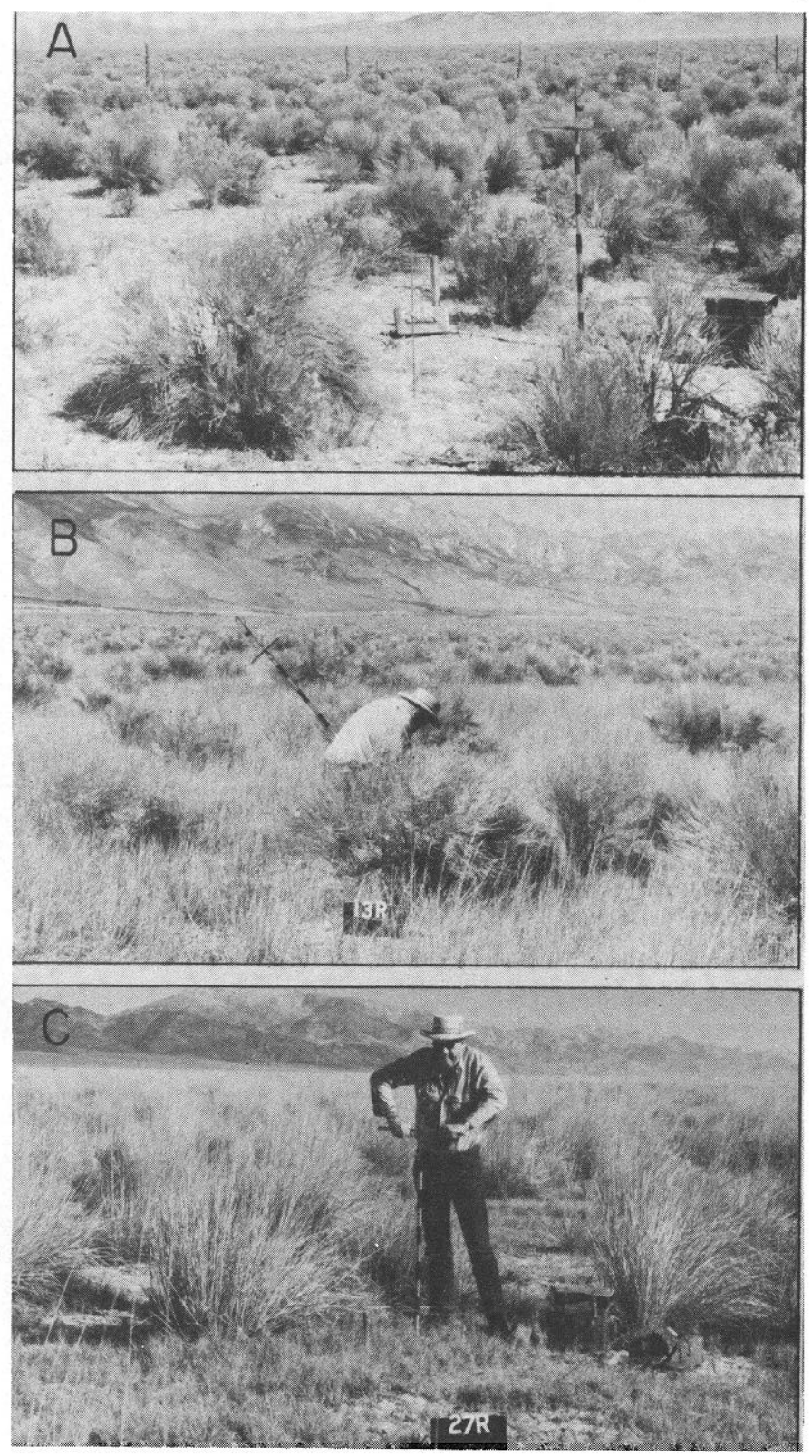

Fig. 4. Plant communities characteristic of bottom sediments where ground water is shallow enough to cause the surface wetting by capillary rise but saturation does not occur at the soil surface. Rubber rabbitbrush occurs with: (A) greasewood, (B) western wheatgrass, and (C) basin wildrye and saltgrass. occurred on all sites with this environment. Rabbitbrush occurs with greasewood (Sarcobatus vermiculatus (Hook.) Torr.) (Fig. 4A) or with stands of grasses such as western wheatgrass (Agropyron smithii Rydb.) (Fig. 4B), basin wildrye (Elymus cinereus Scribn. and Merr.), or saltgrass (Fig. 4C). In the spring, soil near the surface (Fig. 2B) had stress values somewhat higher than expected at capillary equilibrium, but they were close enough to assume that equilibrium had occurred prior to sampling. By fall, the influence of evapotranspiration on the pattern of soil-water stress in the soil profile became quite evident. A relatively uniform level of stress was present at depth but not near the soil surface (Fig. 2B). Maximum stress at the surface was approximately $10^{6}$ $\mathrm{g} / \mathrm{cm}^{2}$. At the base of the profile, stress levels approached those expected at capillary equilibrium.

Environments where water rises into the root zone by capillarity but surface horizons derive moisture from precipitation are shown in Figure 2C. This condition was present on bottom sediments deposited below the lowest off shore bar. Plant communities occur-
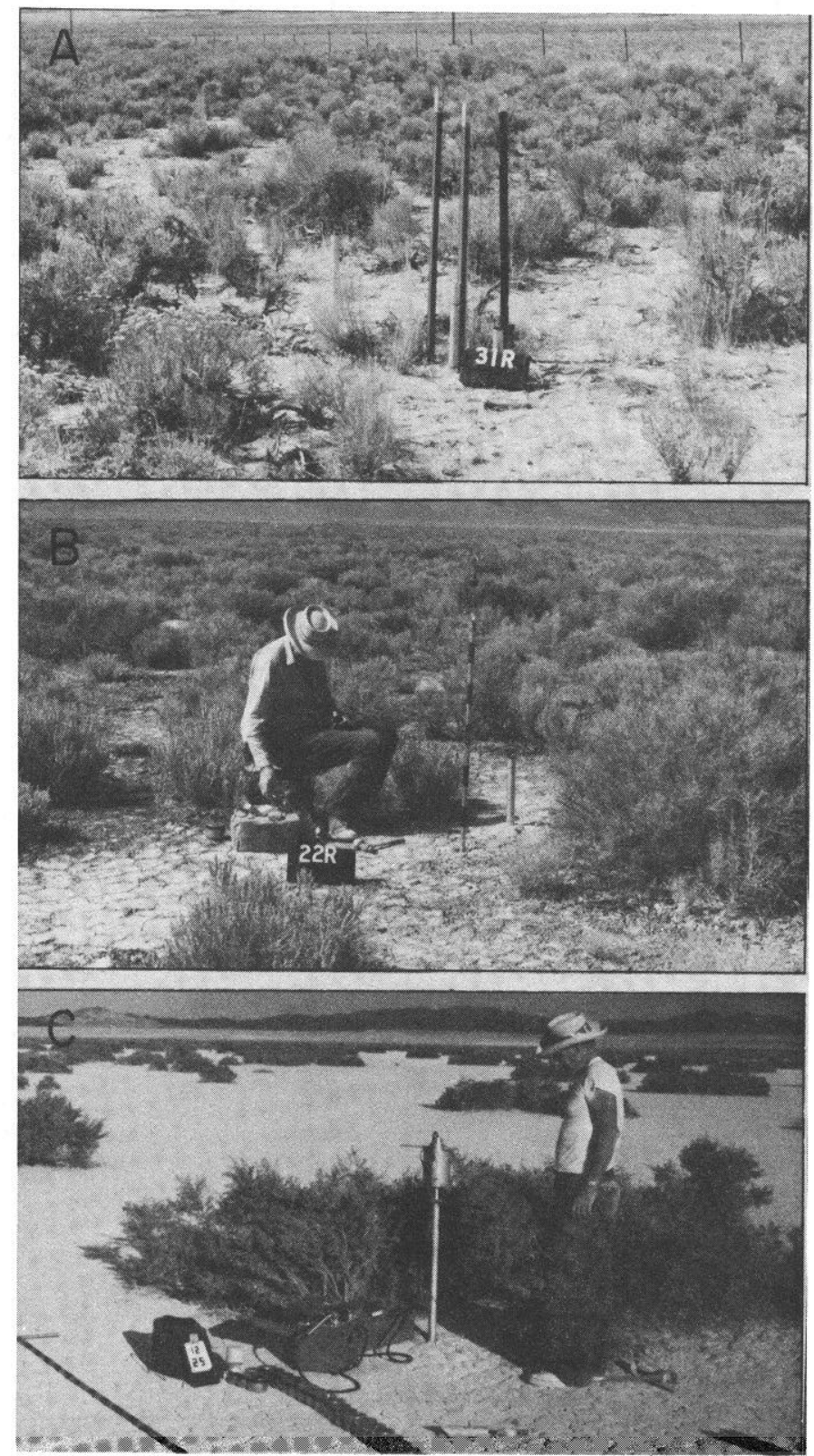

Fig. 5. Plant communities characteristic of sediments deposited below bars. Water from the capillary fringe is available to deep-rooted shrubs such as: (A) big sagebrush and rubber rabbitbrush, (B) shadscale and greasewood, and $(C)$ greasewood. 
ring on sites with this type of environment are illustrated in Figure 5. Big sagebrush (Artemesia tridentada tridentada (Beetle 1960)) mixed with rubber rabbitbrush (Fig. 5A) occurs in sandy material deposited where the Franklin River drained into the lake. Greasewood occurs with shadescale (Atriplex confertifolia (Torr. and Frem.) and Wats.) on medium-textured lake-bottom sediments (Fig. 5B), but greasewood occurs alone on finer bottom sediments (Fig. 5C). The water table in the soil (Fig. 5A) for which data are presented in Figure $2 \mathrm{C}$ occurs approximately $4 \mathrm{~m}(13 \mathrm{ft})$ beneath the surface. In this profile, soil-water stress approached capillary equilibrium to a height of approximately $2.2 \mathrm{~m}(6.6 \mathrm{ft})$ above the water table both in the spring and in the fall. The stress at this height above the water table is $10^{2.34} \mathrm{~g} / \mathrm{cm}^{2}$ and the surface horizon was wetted to levels of stress less than $10^{2} \mathrm{~g} / \mathrm{cm}^{2}$. Levels of stress then increased as depth increased to approximately $10^{3.70} \mathrm{~g} / \mathrm{cm}^{2}$, a stress level that was evident in spring and again in the fall. Stresses in the soil at greater depths decreased progressively to the level reported at the top of the capillary fringe $\left(10^{2.34} \mathrm{~g} / \mathrm{cm}^{2}\right.$. By fall, as in
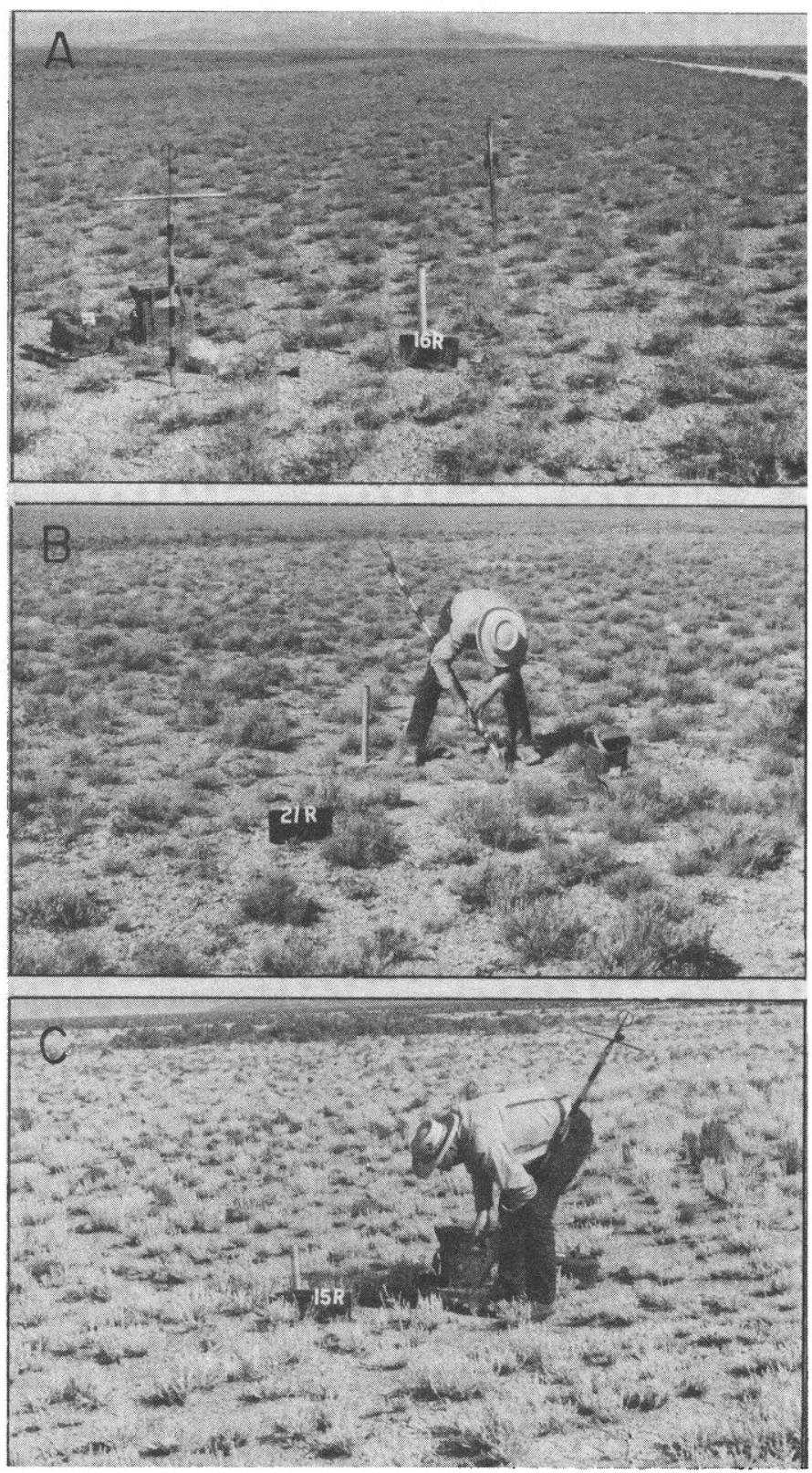

Fig. 6. Plant communities characteristic of coarse bar deposits where only moisture from precipitation is available to vegetation are: (A) black sagebrush, (B) little rabbitbrush, and (C) winterfat. the other environments, a stress gradient approaching $10^{6} \mathrm{~g} / \mathrm{cm}^{2}$ had developed at the surface.

A desert soil-water environment where water tables, if present, are at depths great enough that vegetation is not affected, is illustrated in Figure 2D. The only water available for use by vegetation growing in soils with similar environments is derived from precipitation. This condition occurs in plant communites occupying shore deposits of the ancient lake. Gravelly bar deposits a re occupied by communities of drought-tolerant shrubs (Fig. 6) consisting of either black sage (Artemisia tridentata nova (A. Nels, H. and C.)) and (Fig. 6A), little rabbitbrush (Chrysothamnus viscidiflorus pumilus (Nutt.) H. and C.)) (Fig. 6B), or winterfat (Eurotia lanata Pursh.) (Fig. 6C). Sediments deposited between bars occasionally support stands of winterfat but are generally dominated by other desert shrubs, such as shadscale (Fig. 7A), big sagebrush (Fig. 7B), and Gardner saltbush (Atriplex nuttallii gardneri (Moq.) H. and C.)) (Fig. 7C).

In three of the environments investigated, soil-water stress con-
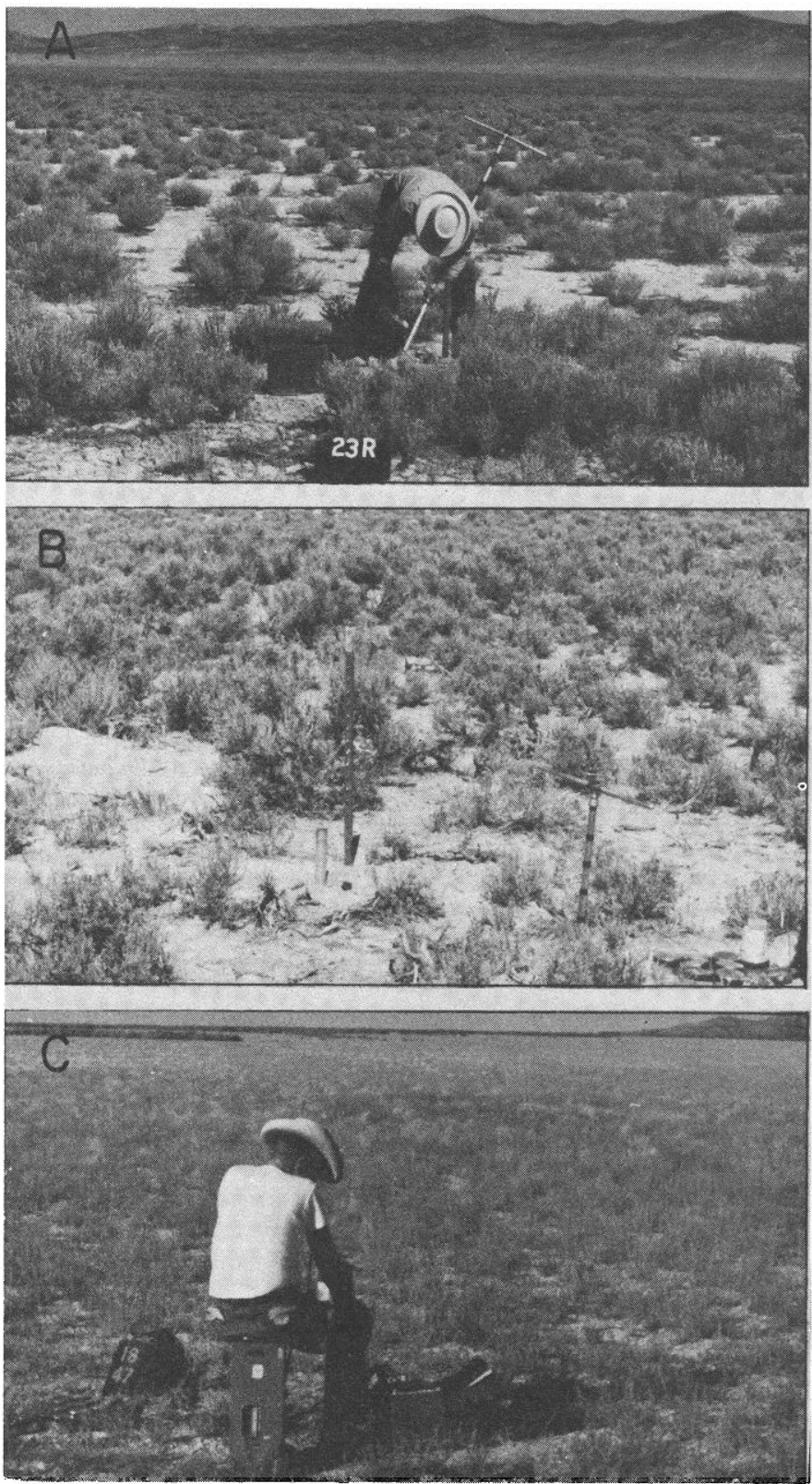

Fig. 7. Plant communities characteristic of finer soil between bars where moisture from precipitation only is available to plant communities are. (A) shadscale, (B) big sagebrush, and (C) Gardner saltbush. 
sistently approached $10^{6} \mathrm{~g} / \mathrm{cm}^{2}$ at the surface under maximum stress conditions. This is apparently the maximum level of stress that can be achieved in the sun-dried soil. Evaporation (E) apparently accounts for the loss of moisture held at stresses greater than the uniform maximum level of stress achieved deeper in the profiles. It is reasonable to assume that a proportionate amount of moisture is lost to evaporation from the surface horizons when moisture is retained at lower levels of stress. Amounts assumed lost by evaporation (E) are illustrated graphically in Fig. 2D. Similar approaches could be used for the environments illustrated in Figs. $2 \mathrm{~B}$ and $2 \mathrm{C}$. This environment is characteristic of desert soils (Miller and McQueen 1972, 1978).

\section{Water-retention Capacities}

The capacity of soils to retain water influenced the distribution of upland desert shrubs deriving moisture only from precipitation. The capacity of a soil to retain water adsorbed as films can be approximated by extending straight lines down from $10^{6.25} \mathrm{~g} / \mathrm{cm}^{2}$ (zero moisture content) through the measured water content at any stress value below $10^{5} \mathrm{~g} / \mathrm{cm}^{2}$ and above $10^{2.34} \mathrm{~g} / \mathrm{cm}^{2}$ (Fig. 8) (McQueen and Miller 1974). Results from desert soils in Ruby Valley indicated that water contents corresponding to stress values less than $10^{2.34} \mathrm{~g} / \mathrm{cm}^{2}$ could also be used if the soil was a meter or more above the water table (Miller and McQueen 1978). This

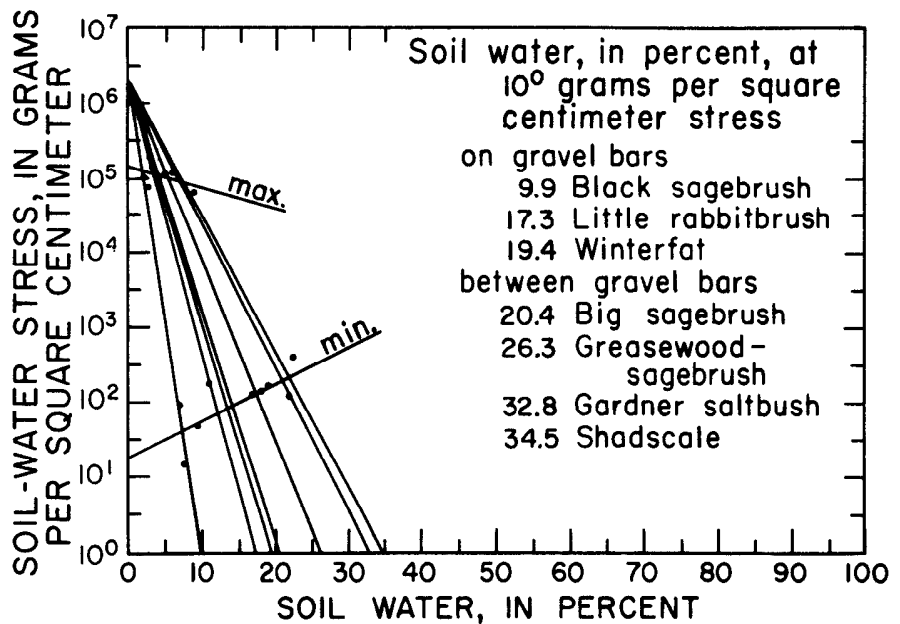

Fig. 8. Average soil-water content and soil-water stress relationship for hydrologically active portions of soil profiles associated with plant communities that are not in contact with a shallow water table. Watercontent values for vegetation types are the average soil-water content at $10^{0} \mathrm{~g} / \mathrm{cm}^{2}$ stress. Average maximum and minimum stress values measured at each site are plotted as points. Regression lines show the change in range of soil-water stress with differences in water-retention capacities of the soils.

procedure was used to define the average soil-water stress and soil-water content relationships of all soils associated with a given plant community (Fig. 8). Each line represents average relationships determined for the solum of the soils concerned. Greatest differences between soils are shown at their computed adsorbed water-retention capacity at $10^{\circ} \mathrm{g} / \mathrm{cm}^{2}$. This value is directly proportional to soil-particle surface area (McQueen and Miller 1974). Bar deposits exhibited the lowest adsorbed water-retention capacities (Fig. 8). Black sagebrush occurred on soils with the lowest adsorbed water-retention capacities and little rabbitbrush occurred on soils with slightly greater adsorbed water-retention capacities than winterfat. The average adsorbed water-retention capacities of soils occurring between bars was greater than on the bars. Plant communities occurring on these soils in order of increasing water-retention capacity were big sagebrush, greasewood-sagebrush, Gardner saltbush, and shadscale (Fig. 8).

Average stress values for the solum at maximum and minimum levels of water retention measured at each sampling site were computed and plotted on the graph in Figure 8. Regression lines were computed and plotted through the data points. There is a direct linear relation ship between average minimum levels of stress found in the solum at the spring sampling and increasing adsorbed water-retention capacity. There is, however, an inverse linear relationship between average maximum levels of stress attained at the fall sampling and the water-adsorption capacity. Thus, as the average water-adsorption capacity of the solum increases, the range of soil stresses becomes narrower, indicating that coarser soils are more moist in spring and drier in fall than fine-textured soils.

\section{Evapotranspiration}

Depletion of soil-water storage may equal evapotranspiration when little or no recharge from precipitation occurs during the growing season and plants do not have access to water from the water table (see Fig. 2D). Evapotranspiration will exceed the seasonal precipitation when plants have access to ground water. For soils with $100 \%$ live plant cover, evapotranspiration may approach evaporation from a free water surface. The relationship between live plant cover and evapotranspiration shown in Figure 9 was derived from those plant communities where valid seasonal depletion of soil moisture was measured. Excluded from this analysis

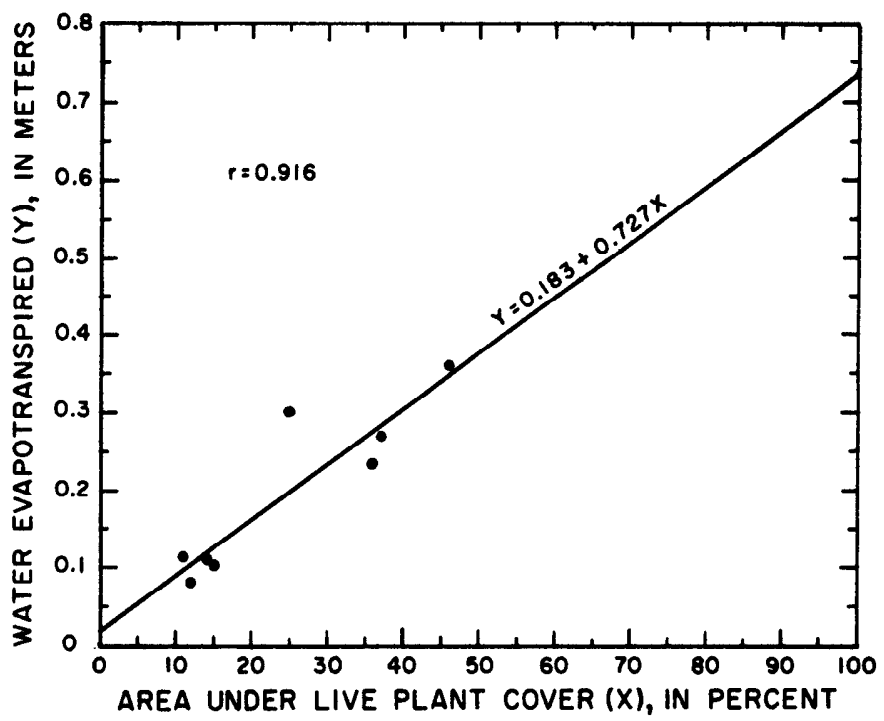

Fig. 9. Relationship between live plant cover and evapotranspiration. Live plant cover includes leaves, stems, and twigs as measured by the firstcontact point-quadrat method. Standing dead material was not included.

were sites with ground water available to plants, because complete data on inflow to the water table were not available. Computational requirements for the analysis include complete data on minimum and maximum water storage to the base of the soil profile. The relationship was then used to estimate the evapotranspiration for all communities shown in Figure 10. Measurements of cover and evapotranspiration for upland species are used to estimate evapotranspiration for lowland species from plant-cover measurements in the more moist habitats. We have no way of testing the reliability of these estimates, but the relationship for upland species is quite good (correlation coefficient of 0.916) and one would expect the extrapolated values to be equally good.

Actual eva potranspiration is probably underestimated for some habitats because inflow to and use from the water table are not adequately defined. Based on this relationship, the largest quantities of water are consistently evapotranspired where a shallow water table rises to the surface at periods of maximum wetness (Fig. 2A). Appreciably less water is evapotranspired where the water table does not rise to the surface, but moisture can rise to the surface by capillarity (Fig. 2B). Even less moisture is evapotranspired where water rising by capillarity becomes available to plant roots, but can migrate to the surface only as film flow. Evapotranspiration from some of the sites where water is derived only from 


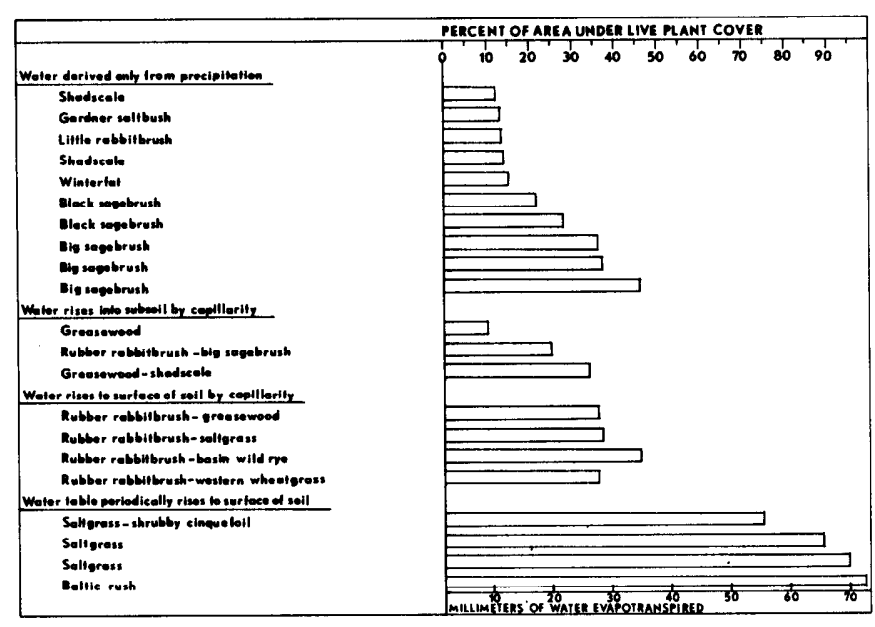

Fig. 10. Estimated evapotranspiration computed for each study site using the regression line shown in Figure 9.

precipitation actually exceeds quantities depleted from the solum where some moisture is available from the water table. This is most likely the result of snow blowing off areas with low-growing shrubs into areas with taller shrubs. Gravelly bars on which these low shrubs occur also stand above the surrounding terrain, making snow more susceptible to removal by winds. Thus, areas covered with big sagebrush benefit from snow, which originally fell on areas covered by shadscale, Gardner saltbush, little rabbitbrush, winterfat, or black sagebrush.

Maximum moisture storage in Ruby Valley results from snowmelt, and snow is the primary source of moisture for plant growth Summer storms seldom yield enough water to have a significant influence on plant growth. The average rainfall for a 2-week period in summer does not exceed $0.5 \mathrm{~cm}$ (0.2 in.) (Gifford et al. 1967).

\section{Energy Relationships of Plants and Soils}

Water is transported from soils, through plants, to the atmosphere in a dynamic continuum. The energy at a point in the transpiration stream should be a function of the flow rate and the energy at another point in the stream. Branson and Shown (1975),

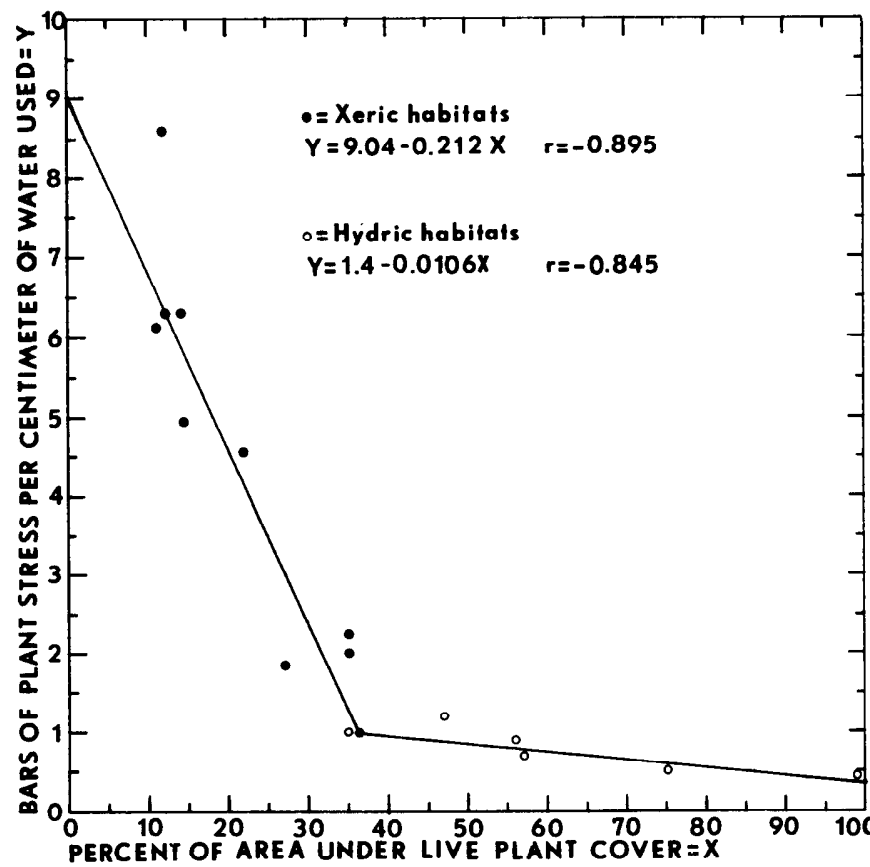

Fig. 11. Relationships between bars of plant stress per centimeter of water evapotranspired and live plant cover measured in xeric and hydric habitats. working with big sagebrush, reported that the internal plant strcss is related to the minimum soil-water stress measured in the root zone. Similar relationships were defined in Colorado for species that a re present in Ruby Valley by Branson et al. (1976). One might cxpect internal-plant stress to show an integration of soil-water stress, but this does not appear to be true. A possible explanation for the relationship is found in the work by Gardner (1965), who found that roots of birdsfoot trefoil had considerably less resistance to water movement than resistance in surrounding mineral soil, thus permitting water to move through roots across soil zones of high resistance from the zone of lowest soil-water stress. McQueen and Miller (1972) found that hyd raulic equilibria may be maintained in soil masses by moisture transported through plant roots.

Separation of vegetation types into xeric and hydric habitats permitted definition of the two transpiration-energy versus plantcover relationships shown in Figure 11. Habitats where roots do not benefit from water rising from the water table are considered to be xeric; habitats where ground water or capillary water is available to roots and considered to be hydric. Appreciably more energy per unit of water is expended to achieve a level of plant cover in xeric habitats than in hydric habitats. The highest levels of stress achieved per unit of water transpired were in habitats with the least water stored in the soil. Thus, the relative capacity of plants to exert energy in obtaining a unit of water is probably one of the factors determining which plant species occur in a given habitat.

Maximum internal-plant stresses and related quantities of water evapotranspired for different plant communities studied are shown in Figure 12. This relationship has a highly significant negative correlation coefficient of 0.92 and partially explains the hydric and xeric relationships shown in Figure 11.

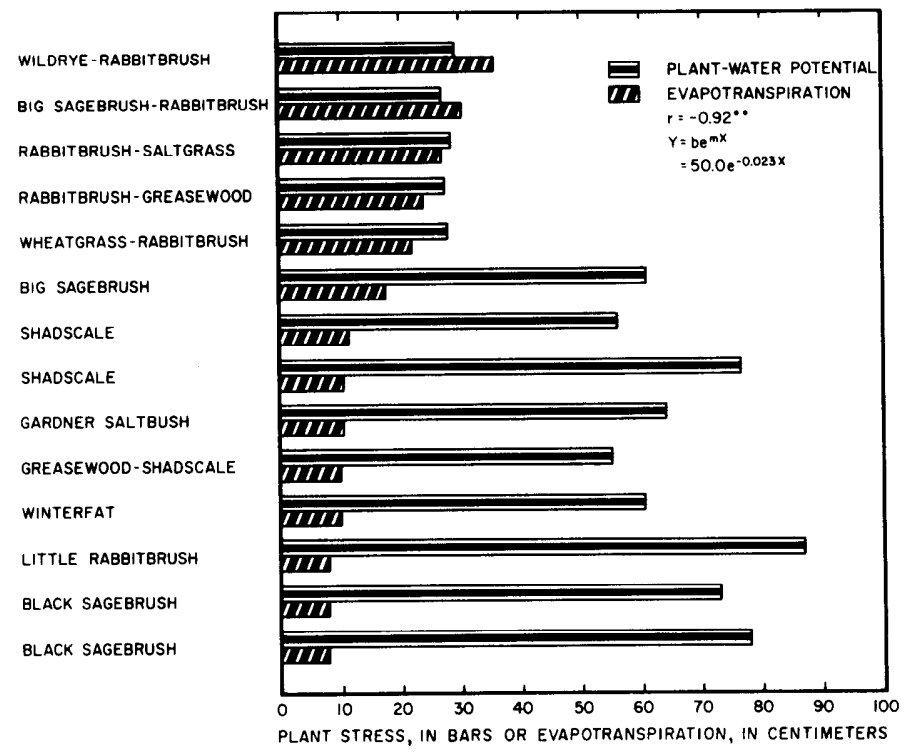

Fig. 12. Maximum internal-plant stresses as related to quantities of water evapotranspired in 14 habitats.

Part of the total stress influencing water availability to plants occurs as osmotic stress resulting from salts present in soils and is particularly important to survival of seedlings. Osmotic moisture stress was determined from the electrical conductivity of saturated soil. Relationships presented by Richards (1954) were used to compute osmotic stress. Only values computcd for surface soils are presented (Fig. 13) because surface soil is assumed to have the most influence on seedling establishment.

Soils with electrical conductivities of saturation extract greater than 4 millimhos/cm (Fig. 13) are considered saline (Richards 1954). Surprisingly, many of the shrubs often considered to be halophytes (Gardner saltbush, shadscale, and winterfat) did not occupy saline sites and several species not usually though of as 
ELECTRICAL CONDUCTIVITY,

PLANT COMMUNITY IN MILLIMHOS PER CENTIMETER AT $25^{\circ} \mathrm{C}$

SALTGRASS (2)

BASIN WILDRYE (I)

BALTIC RUSH (I)

RUBBER RABBITBRUSH

(2)

WESTERN WHEATGRASS

(1)

GREASEWOOD

(2)

SHRUBBY CINQUEFOIL

(1)

BIG SAGEBRUSH

(3)

WINTERFAT (1)

SHADSCALE (2)

GARDNER SALTBUSH

LITTLE RABBITBRUSH

BLACK SAGEBRUSH

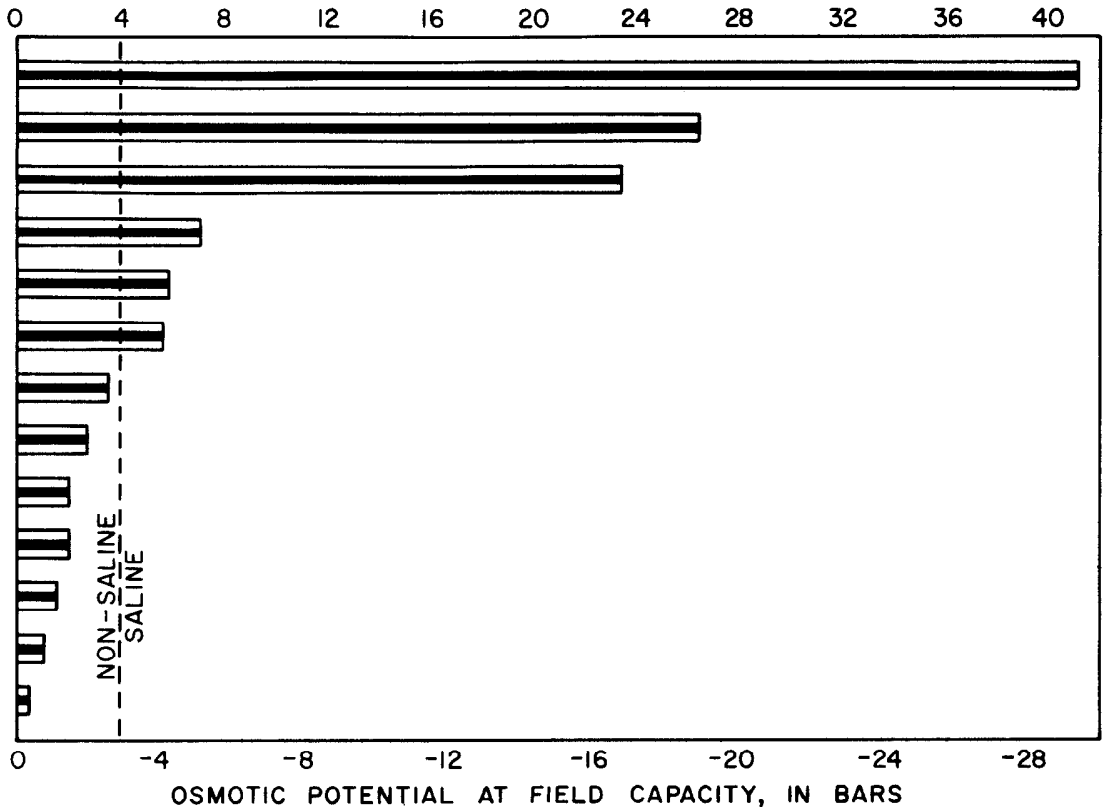

Fig. 13. Levels of electrical conductivity in saturation extracts computed from conductivity of saturated soil (Richards 1954) and related osmotic

being halophytic (western wheatgrass, rubber rabbitbrush, and basin wildrye) grew in salty soils. These results agree with those of Branson et al. (1976) for salt desert shrub communities near Grand Junction, Colo., where rubber rabbitbrush and greasewood occupied saline soils, and big sagebrush, shadscale, and winterfat grew in nonsaline soils.

Highest salt concentrations in surface soils were found where capillary water moved salts to the surface from shallow water tables. Saltgrass exhibited the greatest salt tolerance, as might be expected, but basin wildrye and western wheatgrass had higherthan-exepcted salt tolerances. There is little information in the literature on salt tolerance of western wheatgrass and basin wildrye. Neither species is listed by Unger (1974) in his extensive review of information on inland halophytes. Numerous studies of saltgrass date to the early work of Kearney et al. (1914). Salinity adaptations of saltgrass include salt excretion to reduce toxic effects of excessive salts and high osmotic pressures of cell sap which range from 21.7 to 47.8 atm (Dodd and Coupland 1966). Our electrical conductivity value for saltgrass surface soil is higher than most previously reported for pure stands of the species, but not as high as the 64.0 value for mixed Suaeda depressa and saltgrass near Lincoln, Nebr. (Unger et al. 1969).

For three of the sites (Fig. 13), the osmotic component of total soil-water stress exceeded the 15 bars, sometimes considered to be the wilting point.

\section{Literature Cited}

Beetle, A.A. 1960. A study of sagebrush, the section Tridentatae of Artemisia. Univ. Wyoming Agr. Exp. Sta. Bull. 368, Laramie, Wyo. 88 p.

Branson, F.A., and L.M. Shown 1975. Soil-moisture stress as related to plant moisture stress in big sagebrush. J. Range Manage. 28:212-215.

Branson, F.A., Reuben F. Miller, and I.S. McQueen. 1976. Moisture relationships in twelve northern desert shrub communities near Grand Junction, Colorado. Ecology 57:1104-1124.

Dodd, J.S., and R.T. Coupland.1966. Osmotic pressures of native plants of saline soil in Saskatchewan, Canada. J. Plant Sci. 46:479-485. stress at field capacity measured in surface soils associated with different plant communities.

Gardner, W.R. 1965. Rainfall, runoff, and return. Meterological Monogr. 6:138-148.

Gifford, R.O., G.L. Asheraft, and M.D. Magnuson. 1967. Probability of selected precipitation amounts in the western region of the United States. Univ. Nevada Agr. Exp. Sta. Bull. T-8, Reno, Nev.

Harrington, H.D. 1954. Manual of the plants of Colorado. Sage Books, Denver, Colo. 666 p.

Kearney, T.H., J.L. Briggs, H.L. Shantz, J.W. McLane, and R.L. Piemeisel. 1914. Indicator significance of vegetation in Tooele Valley, Utah. J. Agr. Res. 1:365-417.

Levy, E.B., and E.A. Madden. 1933. The point method of pasture analysis. New Zealand J. Agr. 46:267-279.

McQueen, I.S., and Reuben F. Miller. 1968. Calibration and evaluation of a wide-range gravimetric method for measuring moisture stress. Soil Sci. 106:225-231.

McQueen, I.S., and Reuben F. Miller. 1972. Soil-moisture and energy relationships associated with riparian vegetation near San Carlos, Arizona. U.S. Geolog. Surv. Prof. Pap. 655-E. 51 p.

McQueen, I.S., and Reuben F. Miller. 1974. Approximating soil-moisture characteristics from limited data: Empirical evidence and tentative model. Water Resources Res. 10:521-527.

Miller, R.F., and I.S. McQueen. 1978. Moisture relations in rangelands, western United States. p. 318-321. In: Ist Internat. Rangeland Congr. August 1978, Denver, Colo.

Richards, L.A. editor. 1954. Diagnosis and improvement of sline and alkali soils. U.S. Dep. Agr. Handbook 60. 160 p.

Schofield, R.K. 1935. The pF of the water in soil. In: Transactions, 3rd Internat. Congr. Soil Science 2:34-48.

Snyder, C.T., and W.B. Langbein. 1962. The Pleistocene Lake in Spring Valley, Nevada, and its climatic implications. J. Geophys. Res. 67:23852394.

Unger, I.A., and F. Capilupo. 1969. An ecological life study of Suaeda depressa Pursh Wats. Adv. Front. Plant Sci. 23:137-158.

Unger, I.A. 1974. Inland halophytes of the United States. p 235-305. In: R.J. Reimold and W.H. Queen, eds. Ecology of Halophytes. Academic Press, New York.

Waring, R.H., and B.D. Cleary. 1967. Plant moisture stress: Evaluation by pressure bomb. Science 155:1248-1254. 